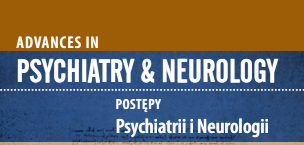

Correspondence to/

Adres do korespondencji:

Krzysztof Śmigórski

11/8 Wojska Polskiego Str.

56-100 Wołów

phone: +48 664010591

e-mail: smigorski@gmail.com

Submitted/Otrzymano: 12.06.2017

Accepted/Przyjęto do druku: 27.06.2017

\section{OLFACTORY DYSFUNCTIONS OCCURRING IN THE COURSE OF PARKINSON'S DISEASE}

\section{ZABURZENIA FUNKCJONOWANIA WĘCHOWEGO W PRZEBIEGU CHOROBY PARKINSONA}

\author{
Krzysztof Śmigórski, Agnieszka M. Śmigórska
}

"Neurona" Neuropsychology Centre

Centrum Neuropsychologii Neurona

\begin{abstract}
Purpose: The aim of this article is to provide a summary of findings concerning the olfactory loss associated with pathological neurodegenerative changes which occur in the course of Parkinson's disease.

Views: Olfactory function deficits occur in the early, prodromal stage of Parkinson's disease and their severity is much higher, especially compared with other neurodegenerative diseases. Information on characteristics of olfactory loss in Parkinson's disease is presented in the article.

Conclusions: Authors indicate that olfactory function assessment is useful in differential diagnosis of neurodegenerative disorders in their prodromal stage and physiological aging. Olfactory ability evaluation may be also very helpful in differential diagnosis of parkinsonism syndromes. Severity of the olfactory impairment may be a good predictor of neuropsychiatric complications development in Parkinson's disease.
\end{abstract}

Key words: Parkinson's disease, olfaction disorders, olfactory perception, dementia, smell.

\title{
Streszczenie
}

Cel: Celem artykułu jest przedstawienie stanu wiedzy na temat utraty sprawności węchowej związanej z patologicznymi zmianami neurozwyrodnieniowymi zachodzącymi w przebiegu choroby Parkinsona.

Poglądy: Zaburzenia sprawności węchowej pojawiają się we wczesnym, prodromalnym etapie rozwoju choroby Parkinsona, a ich natężenie jest większe niż w innych chorobach neurozwyrodnieniowych. W artykule przedstawiono informacje na temat charakterystyki utraty węchu w chorobie Parkinsona.

Wnioski: Autorzy wykazują, że ocena sprawności węchowej jest użyteczna w różnicowaniu zaburzeń neurozwyrodnieniowych w ich prodromalnym stadium $\mathrm{z}$ fizjologicznym starzeniem się. Ewaluacja sprawności węchowej może być również bardzo pomocna w różnicowaniu diagnostycznym zespołów parkinsonowskich. Głębokość zaburzeń węchowych może być dobrym predyktorem rozwoju zaburzeń neuropsychiatrycznych w chorobie Parkinsona.

Słowa kluczowe: choroba Parkinsona, zaburzenia węchu, percepcja węchowa, otępienie, węch. 


\section{OVERVIEW OF NEUROANATOMY STRUCTURES ASSOCIATED WITH THE OLFACTORY FUNCTION IN HUMANS}

Each olfactory processing cycle begins with taking a breath - air with suspended molecules goes through two nasal cavities separated by the nasal septum. The inner surface of the nasal cavities is wrinkled and lined with a mucous membrane that is approx. $150 \mu \mathrm{m}$ thick, secreted by Bowman's glands and goblet cells. The mucous membrane contains two types of cells, namely respiratory cells and sensory cells. Sensory neurons are grouped in a small section of the olfactory region (Latin: area olfactoria), which contains olfactory epithelium. It is located approx. $7 \mathrm{~cm}$ along the nasal cavities and its area is approx. $1.5-2.5 \mathrm{~cm}^{2}$ [1].

Sensory cells are grouped in bundles which go on both sides through the cribriform plate located in the anterior cranial fossa. Their axons reach both olfactory bulbs located below the frontal lobes and specifically below the sulcus that separates the gyrus rectus and medial orbitofrontal gyrus in both cerebral hemispheres $[2,3]$.

The first station of the olfactory pathway is the olfactory bulb (OB). The olfactory bulb is small and delicate (average length: 6-14 mm, average width: $3.7 \mathrm{~mm}$ ). The olfactory bulb connects ipsilaterally (i.e. on the same side of the body) to olfactory nerves. Nerve projections are sent from olfactory bulbs to the next central brain structures on the same ipsilateral basis. It is thought that stimulation of olfactory receptors by odour molecules is transformed in the olfactory bulb into olfactory maps. "Map" is an abstract concept here as it refers to a temporary pattern of trains of spikes which are read by centres located more centrally [4]. The olfactory bulb is a region where some of the earliest neuropathological changes associated with Parkinson's disease appear and damage to the olfactory bulb is common in this disease [5-7].

The next stop on the olfactory processing path is the primary olfactory cortex (POC). This name does not refer to a single region, but contains various spatially dispersed structures. The centres forming the cortex were named primary cortex due to the greatest number of connections from the olfactory bulb, which are directed towards them [8]. The secondary olfactory cortex (SOC) is also a set of dispersed cortical and subcortical structures which receive connections from the primary olfactory cortex. It is worth noting that 9 out of 22 centres of the olfactory cortex involved in the processing of olfactory information receive direct connections from the primary olfactory cortex with the exclusion of the thalamus [4]. While we know quite a lot about the peripheral structures of the olfactory sys-

\section{OMÓWIENIE STRUKTUR NEUROANATOMICZNYCH ZWIAZZANYCH Z FUNKCJONOWANIEM WĘCHOWYM CZŁOWIEKA}

Każdy cykl przetwarzania węchowego zaczyna się od wdechu. Powietrze wraz z molekułami w nim zawieszonymi przechodzi przez dwie jamy nosowe przedzielone przegrodą nosową (nasal septum). Powierzchnia wewnętrzna jam nosowych jest pofałdowana, pokryta błoną śluzową o grubości ok. $150 \mu \mathrm{m}$, produkowaną przez gruczoły Bowmana i komórki kubkowe (goblet cells). Błona śluzowa zawiera dwa typy komórek - oddechowe (respiratory cells) i sensoryczne. Neurony sensoryczne są zgrupowane w małej części rejonu węchowego (łac. area olfactoria), która zawiera nabłonek węchowy (olfactory epithelium). Jest on zlokalizowany w jamach nosowych na długości ok. $7 \mathrm{~cm}$ i zajmuje ok. 1,5-2,5 $\mathrm{cm}^{2}$ [1].

Komórki sensoryczne są zgrupowane w wiązki, które przechodzą dwustronnie przez płytkę kostną zwaną blaszką sitową (cribriform plate), znajdującą się w przednim dole czaszki (anterior cranial fossa). Ich aksony sięgają obu opuszek węchowych położonych pod płatami czołowymi, a dokładnie pod bruzdą węchową, która oddziela zakręt prosty (gyrus rectus) od środkowego zakrętu okołooczodołowo-czołowego (medial orbitofrontal gyrus) w obu półkulach mózgowych [2,3].

Pierwszą stacją szlaku węchowego jest mała, delikatna opuszka węchowa (olfactory bulb), o długości ok. 6$14 \mathrm{~mm}$ i szerokości ok. 3,7 mm, która łączy się ipsilateralnie (tzn. po tej samej stronie ciała) z nerwami węchowymi; na tej samej, ipsilateralnej, zasadzie wysyłane są projekcje nerwowe z opuszek węchowych do kolejnych ośrodkowych struktur mózgowych. Uważa się, że pobudzenie receptorów węchowych przez cząsteczki zapachowe jest przekształcane w opuszce węchowej w mapy węchowe. Pojęcie „mapy” ma tutaj charakter abstrakcyjny, gdyż odnosi się do czasowego wzorca ciągów iglic elektrycznych (spikes), odczytywanych przez ośrodki położone bardziej centralnie [4]. Opuszka węchowa jest rejonem, gdzie pojawiają się jedne z najwcześniejszych zmian neuropatologicznych związanych z chorobą Parkinsona (Parkinson's disease - PD), a jej uszkodzenie jest powszechne w tej chorobie [5-7].

Następnym przystankiem na szlaku przetwarzania węchowego jest pierwszorzędowa kora węchowa (primary olfactory cortex). Nazwa ta nie odnosi się pojedynczego rejonu, ale różnych rozproszonych przestrzennie struktur, które zyskały miano kory pierwszorzędowej ze względu na największą liczbę połączeń $\mathrm{z}$ opuszki węchowej, które są do nich kierowane [8]. Drugorzędową korę węchową (secondary olfactory cortex) też stanowi zbiór rozproszonych struktur korowych i podkorowych, które otrzymują połączenia z pierwszorzędowej kory węchowej. Warto zwrócić uwagę, że 9 spośród 22 ośrodków kory węchowej zaanga- 
tem, neurophysiology and processing of information taking place in the tertiary olfactory cortex require further research. The temporal structures that jointly form the tertiary olfactory cortex seem to be associated more with the memory of odours than with their perception itself. On the other hand, the insula and orbitofrontal cortex are the areas whose involvement in the olfactory perception processes is consistently confirmed in various studies using neuroimaging techniques $[2,9]$.

Neuroanatomical and neurophysiological studies so far have not produced conclusive decisions as to the structural or functional differences in the brain structure, which could explain individual differences in the olfactory function.

\section{NEUROANATOMICAL BASIS OF THE OLFACTORY FUNCTION LOSS IN PARKINSON'S DISEASE}

The peak olfactory function occurs between the ages of 20 and 40 [10] and begins to decline after this age [11]. The percentage of objectively confirmed olfaction disorders increases from $11-24 \%$ in middle-aged people to $37-70 \%$ in the elderly $[10,12]$. The decrease in the olfactory function occurs in at least $50 \%$ of people over the age of 65 and $62-80 \%$ of people over the age of 80 [13]. About half of the United States population between 65 and 80 years of age suffers from some degree of smell loss [14]. There are a number of neuroanatomical changes that are likely to underlie a decline in the olfactory function that is reduced with age: 1) the area of the olfactory epithelium is reduced; 2) the density and complexity of adrenergic connections in the lamina propria is reduced; 3 ) the number of mitral cells in the olfactory bulb declines (from 60,000 at the age of 25 to 14,500 at the age of 95); 4) olfactory nerve fibres enter deeper parts of the olfactory bulb and form glomeruli outside the normal glomerular layer area [10].

Different nature of olfactory dysfunction in PD compared to physiological ageing suggests the presence of other additional neuropathological changes. Basically, olfactory dysfunction in PD is clearly to a greater extent associated with pathology of Lewy bodies than neurofibrillary tangles [15]. Neuropathology associated with PD can spread in the brain by three pathways [16]: 1) from the brain stem;2) from olfactory bulbs to the limbic system; and 3) within the neocortex. From the point of view of this study, particularly noteworthy are neuropathological changes that start in the olfactory bulb, anterior olfactory nucleus and dorsal motor nucleus of vagal glossopharyngeal nerve complex, as they are likely to lead to the development of PD phenotype associated with olfactory dysfunction [17]. żowanych w przetwarzanie informacji węchowej otrzymuje bezpośrednie połączenia $\mathrm{z}$ pierwszorzędowej kory węchowej z pominięciem wzgórza [4]. O ile wiadomo stosunkowo dużo o peryferyjnych strukturach układu węchowego, neurofizjologia i przetwarzanie informacji zachodzące w trzeciorzędowej korze węchowej wymagają dalszych badań. Struktury skroniowe współtworzace trzeciorzędową korę węchową wydają się związane bardziej z pamięcią zapachów niż z samą ich percepcją. Z kolei wyspa i kora oczodołowo-czołowa to obszary, których zaangażowanie w procesy percepcji węchowej jest spójnie potwierdzane w badaniach z wykorzystaniem technik neuroobrazowania $[2,9]$.

Badania neurofizjologiczne i neuroanatomiczne nie przyniosły dotychczas jednoznacznych rozstrzygnięć dotyczących różnic strukturalnych lub funkcjonalnych w budowie mózgu, które mogłyby wyjaśnić różnice indywidualne dotyczące sprawności węchowej.

\section{NEUROANATOMICZNE PODSTAWY UTRATY SPRAWNOŚCI WĘCHOWEJ W CHOROBIE PARKINSONA}

Szczytowe funkcjonowanie węchowe przypada na wiek 20-40 lat [10], później sprawność węchu zaczyna się obniżać [11]. Odsetek obiektywnie potwierdzonych zaburzeń węchu wzrasta z 11-24\% w wieku średnim do 37-70\% w wieku podeszłym $[10,12]$. Spadek sprawności węchu dotyczy co najmniej $50 \%$ osób powyżej 65 . roku życia oraz $62-80 \%$ powyżej 80. roku życia [13]. W USA około połowa populacji w wieku 65-80 lat cierpi na różnego stopnia utratę sprawności węchu [14]. Wymienia się szereg zmian neuroanatomicznych, które najprawdopodobniej leżą u podstaw spadku sprawności węchowej postępującej wraz z wiekiem: 1) zmniejsza się powierzchnia nabłonka węchowego, 2) zmniejsza się gęstość i złożoność połączeń adrenergicznych w blaszce właściwej (lamina propria), 3) zmniejsza się liczba komórek mitralnych w opuszce węchowej (z 60000 w 25. roku życia do 14500 w 95. roku życia), 4) włókna nerwów węchowych wkraczają w głębsze partie opuszki węchowej i formują kłębuszki (glomeruli) poza normalnym dla nich obszarem warstwy kłębuszkowej [10].

Odmienny charakter zaburzeń węchowych w PD $\mathrm{w}$ porównaniu ze starzeniem się fizjologicznym sugeruje obecność innych, dodatkowych zmian neuropatologicznych. Zasadniczo zaburzenia węchowe w PD są wyraźnie bardziej związane z patologią ciałek Lewy’ego niż złogów neurofibrylarnych [15]. Neuropatologia związana z PD może się rozprzestrzeniać w mózgu trzema szlakami [16]: 1) z pnia mózgu, 2) od opuszek węchowych do układu limbicznego oraz 3) w ramach kory nowej. Z punktu widzenia niniejszej pracy szczególnie warte uwagi są zmiany neuropatologiczne zaczynające się wewnątrz opuszki węchowej, przedniego jądra węchowego (anterior olfactory nucleus) oraz brzusznego jądra ruchowego kompleksu 
The studies involving hyposmic patients suffering from PD demonstrate that atrophic changes in primary and secondary regions of the olfactory system, i.e. in the olfactory bulb, piriform cortex and orbitofrontal cortex, are responsible for the observed decrease in the olfactory function as well as frequent lack of awareness of this deficit [18-22]. Furthermore, PD patients have difficulty in appreciating hedonic guidance when identifying odours as the circuit responsible for processing of hedonic information is also damaged in $\mathrm{PD}$ [23]. It is suggested that decreased dopaminergic and cholinergic innervation in temporal and limbic regions as well as reduced metabolism in the amygdala and piriform cortex regions are responsible for olfactory dysfunction in PD. Neuroanatomic studies suggest reduced density of gray and white matter in the orbitofrontal cortex and limbic system regions as changes responsible for the reduction in olfactory function in PD [24]. However, the attempts to link atrophic changes to the level of the olfactory function bring about contradictory results [23].

The role of dopamine in the occurrence of the olfactory system pathology is unclear as the overexpression of dopaminergic cells of the olfactory bulb glomerular layer is a common feature of PD [25]. It appears that abnormal neurogenesis caused by dopamine deficiency can induce smell deficits - as suggested by the results of tests in rodents [26]. Furthermore, the olfactory symptoms do not disappear after the dopaminergic therapy. This indicates the involvement of other neurotransmission systems (such as cholinergic, serotonergic and noradrenergic) and pathology located outside the substantia nigra region (e.g. in the limbic system) [23].

\section{OLFACTORY DYSFUNCTION IN PARKINSON'S DISEASE}

Olfactory dysfunction in Parkinson's disease was for the first time described by Anasari and Johnson in 1975 [27]. The scientific research carried out in the 1970s of the twentieth century has demonstrated an increased detection threshold and deficits in differentiation between odours in PD compared to physiological ageing. Over time, it was discovered that odour identification is also impaired [28]. Currently, it is considered to be a well-acknowledged fact that olfactory dysfunction is present in all three types of PD (tremulous, akinetic-hypertonic and mixed). It is reflected in the emphasis on the role of smell testing in the diagnosis by the Movement Disorders Society $[29,30]$ - the use of olfactory function tests are recommended as an effective screening tool in the PD diagnosis as it measures the presence of one of the earliest prodromal symptoms. In accordance with the recommendations, the diagnosis of hyposmia should motivate błędnego nerwu językowo-gardłowego (dorsal motor nucleus of vagal glossopharyngeal nerve complex), gdyż to one najprawdopodobniej prowadzą do wykształcenia się fenotypu PD związanego z dysfunkcją węchową [17].

Badania hipozmicznych pacjentów cierpiących na PD wskazują, że zmiany atroficzne w obszarach pierwszo- i drugorzędowych systemu węchowego - opuszce węchowej, korze gruszkowatej oraz korze okołooczodołowej - są odpowiedzialne za obserwowany spadek sprawności węchowej, a także częsty brak świadomości tego deficytu [18-22]. Ponadto pacjenci z PD mają trudności z docenianiem wskazówek hedonicznych w czasie identyfikowania zapachów, gdyż uszkodzony jest u nich również obwód odpowiedzialny za przetwarzanie informacji hedonicznej [23]. Sugeruje się, że za dysfunkcje węchowe w PD odpowiada zmniejszone unerwienie dopaminergiczne i cholinergiczne w obszarach skroniowo-limbicznych oraz obniżony metabolizm w obszarach ciała migdałowatego i kory gruszkowatej. Chociaż badania neuroanatomiczne wskazują na zmniejszoną gęstość istoty szarej i białej w obszarach kory okołooczodołowej oraz układu limbicznego jako zmiany odpowiedzialne za osłabienie sprawności węchowej w PD [24], próby powiązania zmian atroficznych z poziomem sprawności węchowej dają nadal sprzeczne wyniki [23].

Niejasna jest rola dopaminy w powstawaniu patologii systemu węchowego, gdyż nadekspresja komórek dopaminergicznych warstwy kłębuszkowatej opuszki węchowej (olfactory bulb glomerular layer) to powszechna cecha PD [25]. Wydaje się, że zaburzenia neurogenezy na skutek niedoboru dopaminy mogą wywoływać deficyty węchu, co sugerują wyniki badań na gryzoniach [26]. Ponadto objawy węchowe nie ulegają wycofaniu pod wpływem leczenia dopaminergicznego. Wskazuje to na zaangażowanie innych systemów neurotransmisji (np. cholinergicznego, serotoninergicznego, noradrenergicznego) oraz istnienie patologii zlokalizowanej poza obszarem istoty czarnej (np. w układzie limbicznym) [23].

\section{WYSTĘPOWANIE ZABURZEŃ WĘCHU W CHOROBIE PARKINSONA}

Zaburzenia węchowe w PD zostały po raz pierwszy opisane przez Anasari i Johnsona w 1975 r. [27]. Badania naukowe $\mathrm{z}$ lat 70 . XX w. wykazały podwyższony próg detekcji oraz deficyty rozróżniania zapachów w $\mathrm{PD}$ w porównaniu ze starością fizjologiczną. Z czasem odkryto, że zaburzona jest również identyfikacja zapachów [28]. Obecnie uważa się za dobrze potwierdzone, że zaburzenia sprawności węchowej są obecne we wszystkich trzech typach PD ( $\mathrm{z}$ dominującym drżeniem, akinetyczno-hipertonicznym i postaci mieszanej). Znalazło to swoje odzwierciedlenie $\mathrm{w}$ podkreśleniu roli badania węchu w diagnostyce przez Movement Disorders Society [29, 30] - stosowanie testów sprawności węchowej jest rekomendo- 
clinicians to use other PD-specific tests. The presence of idiopathic hyposmia, with the absence of other prodromal symptoms, means an increase in the risk of development of Parkinson's disease by at least $10 \%$ to $22 \%$ $[31,32]$. However, in healthy individuals showing deterioration in both cognitive and olfactory measurements, it is estimated that the likelihood of mild cognitive impairment (MCI) increases to $87 \%$ [33].

Olfactory dysfunction affects approximately $75-90 \%$ of people suffering from Parkinson's disease. The estimate values range from $45 \%$ to $98 \%$ of this population $[27,32,34,35]$. Asymptomatic relatives of PD patients also suffer from hyposmia [35]. Seventy-five percent of patients show an increased olfactory detection threshold and 90\% - olfactory identification impairment [10]. The prevalence of olfactory dysfunction induces researchers to believe that normosmic PD patients may represent a very rare unique phenotype [37]. Normal odour identification ability is so rare in PD that reconsideration of the diagnosis is recommended when such normal odour identification ability is found. The only exception is the situation where the patient is a woman with tremor as the predominant symptom [38]. Olfactory dysfunction is considered to be one of the most evident and earliest prodromal symptoms of $\mathrm{PD}$, which precedes the occurrence of motor symptoms by $4-7$ years $[15,25,26,39,40]$ and is a biomarker in two other synucleinopathies: incidental Lewy body disease and REM sleep behaviour disorders [36]. Approximately 80\% of patients suffer from hyposmia, but not from anosmia - and are not aware of the loss of smell or significantly underestimate it [25]. The lack of awareness of hyposmia is closely associated with the occurrence of mild cognitive impairment in PD [18]. Parkinson's disease and MCI patients get lower olfactory function scores, but at the same time they rate their olfactory function higher than cognitive normal PD patients. In summary, severe olfactory dysfunction is associated with cognitive impairment in PD [16, 25, 32, 37, 41, 42] and implies earlier conversion into dementia [18, 43, 44].

It should be emphasised that the degree of identification disorders is independent of the level of cognitive performance in patients suffering from PD and undertaken treatment [34]. Furthermore, the degree of degeneration of dopaminergic cells of the nigrostriatal pathway is not related to the severity of olfactory impairment. Also factors such as age, smoking, degree of physical disability and duration of the disease do not affect the scores obtained by persons administered the olfactory function test. Importantly, PD patients demonstrate significantly lower olfactory function compared to patients suffering from other neurodegenerative disorders [32].

There are some differences in the olfactory function associated with the clinical picture of PD. Studies examining this issue from the perspective of time dy- wane jako skuteczne narzędzie przesiewowe $\mathrm{w}$ diagnostyce PD, gdyż mierzy obecność jednego z najwcześniejszych objawów prodromalnych. Zgodnie z rekomendacjami stwierdzenie hipozmii powinno motywować klinicystów do zastosowania innych testów specyficznych dla PD. Obecność idiopatycznej hipozmii, przy braku innych objawów prodromalnych, wiąże się ze zwiększeniem ryzyka rozwoju PD o co najmniej 10-22\% [31, 32]. W przypadku osób zdrowych wykazujących pogorszenie na obu miarach, poznawczej i węchowej, szacuje się, że prawdopodobieństwo rozwoju łagodnych zaburzeń poznawczych (mild cognitive impairment - MCI) wzrasta do 87\% [33].

Zaburzenia węchowe dotykają ok. 75-90\% osób chorujących na $\mathrm{PD}$, przy czym rozrzut wartości oszacowań waha się w przedziale $45-98 \%$ tej populacji $[27,32,34,35]$. Asymptomatyczni krewni pacjentów z PD też cierpią na hipozmię [35]. U 75\% pacjentów stwierdza się podwyższenie progu detekcji węchowej, a u 90\% zaburzenia identyfikacji węchowej [10]. Powszechność zaburzeń węchowych skłania badaczy do twierdzenia, że normozmiczni pacjenci z PD mogą stanowić bardzo rzadki, unikalny fenotyp [37]. Normalna zdolność identyfikacji zapachu jest tak rzadka w PD, że zaleca się ponowne rozważenie diagnozy, gdy się ją stwierdzi. Jedynym wyjątkiem jest sytuacja, w której pacjent jest kobietą z drżeniem jako dominującym objawem [38]. Zaburzenia węchowe uważane są za jeden z najwyraźniejszych i najwcześniejszych objawów prodromalnych PD, który wyprzedza pojawienie się objawów motorycznych o $4-7$ lat $[15,25,26,39,40]$ i jest biomarkerem $w$ dwóch innych synukleinopatiach: incydentalnej chorobie ciałek Lewy'ego oraz zaburzeniach zachowania podczas snu fazy REM [36]. Ok. 80\% pacjentów cierpi na hipozmię, lecz nie anozmię - i nie jest świadomych utraty węchu lub ją zdecydowanie niedoszacowuje [25]. Brak świadomości hipozmii jest blisko powiązany $\mathrm{z}$ występowaniem MCI w przebiegu PD [18]. Pacjenci z PD oraz MCI uzyskują niższe wyniki sprawności węchowej, lecz jednocześnie oceniają swoją sprawność węchową wyżej niż pacjenci z PD bez zaburzeń poznawczych. Reasumując, silna dysfunkcja węchowa jest związana z zaburzeniami poznawczymi w PD [16, $25,32,37,41,42]$ oraz implikuje wcześniejszą konwersję w otępienie [18, 43, 44].

Należy podkreślić, że stopień zaburzeń identyfikacji jest niezależny od poziomu sprawności poznawczej pacjenta cierpiącego na PD oraz podjętego leczenia [34]. Ponadto stopień degeneracji komórek dopaminergicznych szlaku nigrostriatalnego jest niezwiązany z głębokością zaburzeń węchowych. Również takie czynniki, jak wiek, palenie papierosów, stopień niesprawności ruchowej i długość trwania choroby, nie mają wpływu na wyniki uzyskane przez badanych w teście sprawności węchowej. Co istotne, pacjenci cierpiący na PD mają istotnie gorszą sprawność węchu w porównaniu z chorymi cierpiącymi na inne zaburzenia neurozwyrodnieniowe [32]. 
namics show that PD patients with tremor and without tremor demonstrate similar olfactory impairment, but the loss of smell is lower in patients with the family history of tremor compared to patients without such a history [45]. Forty-six percent of PD patients demonstrate significantly lower odour detection ability compared to healthy subjects. Thirty-four percent of patients are ranked 2 standard deviations below the mean for the control group in terms of differentiation between odours. Seventy-one percent of PD patients score much worse compared to the healthy population as far as odour identification is concerned. Furthermore, PD patients have a narrower range of scores in the hedonic dimension, i.e. in evaluating odours as pleasant/unpleasant. Their scores are grouped closer to the centre of the scale [46]. There is also a correlation between the severity of impairment of the ability to differentiate between odours and the progress of PD [29].

\section{OLFACTORY DYSFUNCTION AND OTHER CLINICAL ASPECTS OF PARKINSON'S DISEASE}

Parkinson's disease patients with the greatest severity of olfactory dysfunction show [33]: 1) more severe nonmotor symptoms (anxiety and autonomous reactions); 2) a significantly lower level of beta amyloid and significantly higher level of tau protein in the cerebrospinal fluid; 3) greater cognitive impairment. Hyposmia in PD is bilateral in nature and is independent of the severity and duration of the disease [39]. However, there is no correlation between the severity of olfactory dysfunction and depression in PD [47].

Patients with impaired smell more often experience psychotic symptoms such as delusions and visual hallucinations. Psychotic symptoms accompanying hyposmia and cognitive impairment may reflect anatomic distribution of the Lewy type pathology and suggest damage located outside the nigrostriatal system [48].

Correlations as far as changes in the olfactory function after diagnosing Parkinson's disease are concerned were also analysed [49]. In one of the study devoted to this issue, the level of olfactory function was measured at two points in time - approximately 3.6 years and 6.8 years after the PD diagnosis. Patients from the lowest olfactory function quartile had a higher risk of developing hallucinations and cognitive deterioration. No correlations were found between the olfactory function and dyskinesia, but a correlation with the risk of falls was observed. The authors conclude that the level of the olfactory function may be more a marker of pathology outside the nigrostriatal system and the severity of olfactory impairment may be a good predictor of the development of neuropsychiatric complications in PD. Similar results were obtained
Występują pewne różnice sprawności węchowej związane $\mathrm{z}$ obrazem klinicznym PD. Z badań poświęconych temu zagadnieniu z perspektywy dynamiki czasowej wiadomo, że zarówno pacjenci z drżeniem, jak i bez drżenia wykazują podobne zaburzenia węchowe, aczkolwiek utrata węchu jest mniejsza u pacjentów $\mathrm{z}$ rodzinną historią drżenia $\mathrm{w}$ porównaniu $\mathrm{z}$ chorymi bez takiej historii [45]. Wśród pacjentów cierpiących na PD 46\% cechuje znacznie obniżona $\mathrm{w}$ porównaniu $\mathrm{z}$ osobami zdrowymi zdolność wykrywania zapachów. Z kolei 34\% pacjentów lokuje się dwa odchylenia standardowe poniżej średniej dla grupy kontrolnej w zakresie rozróżniania zapachów. W grupie pacjentów cierpiących na PD 71\% wypada znacznie gorzej w porównaniu ze zdrową populacją w zakresie identyfikacji zapachów. Ponadto pacjenci z PD mają zawężony zakres ocen w wymiarze hedonicznym, tzn. wartościowaniu zapachu ze względu na walor jego przyjemności-nieprzyjemności. Ich oceny są zgrupowane bliżej środka skali [46]. Istnieje również związek między głębokością zaburzeń rozróżniania zapachów a zaawansowaniem PD [29].

\section{DYSFUNKCJA WĘCHOWA A INNE ASPEKTY KLINICZNE CHOROBY PARKINSONA}

Pacjenci z PD cechujący się największą głębokością zaburzeń sprawności węchowej wykazują [33]: 1) bardziej nasilone symptomy niemotoryczne (lęk i reakcje autonomiczne), 2) w płynie mózgowo-rdzeniowym poziom amyloidu $\beta$ jest istotnie niższy, a poziom białka tau istotnie wyższy, 3) większe pogorszenie sprawności poznawczej. Hipozmia w przebiegu PD ma charakter bilateralny, a jej wielkość nie jest zależna od nasilenia i długości choroby [39]. Nie stwierdza się natomiast związku między głębokością zaburzeń węchowych a depresją w przebiegu PD [47].

Pacjenci z zaburzeniami węchu częściej cierpią na symptomy psychotyczne, takie jak złudzenia oraz halucynacje wzrokowe. Objawy psychotyczne towarzyszące hipozmii i zaburzeniom poznawczym mogą odzwierciedlać anatomiczny rozkład patologii typu Lewy'ego oraz sugerują uszkodzenia zlokalizowane poza czarnoprążkowiem [48].

Przeanalizowano również związki dotyczące zmian sprawności węchowej, które zaszły po zdiagnozowaniu PD [49]. W jednym z poświęconych temu celowi badań mierzono poziom sprawności węchowej w dwóch punktach czasowych - ok. 3,6 roku i 6,8 roku po diagnozie PD. Pacjentów z najniższego kwartyla sprawności węchowej cechowało wyższe ryzyko rozwoju halucynacji i rozpadu poznawczego. Nie stwierdzono związków między sprawnością węchową a występowaniem dyskinezy, aczkolwiek zaobserwowano związek z ryzykiem upadków. Autorzy konkludują, że poziom sprawności funkcjonowania węchowego może być bardziej markerem patologii pozaczarnoprążkowej, a głębokość zaburzeń węchowych może 
in other study lasting 10 years. Forty-six percent of PD patients participating in the study, who were diagnosed with hyposmia at the beginning of the study, developed dementia within 10 years. For comparison, the conversion into dementia occurred in only $21 \%$ of normosmic patients [35].

The degrees of the risk of the development of olfactory dysfunction in PD were estimated based on longitudinal studies [50]. On their basis it was concluded that PD patients aged 45-65 are characterised by 12.74 times higher probability of anosmia or hyposmia compared to healthy subjects at the same age. In PD patients aged $>80$ this risk is 74.01 times higher compared to healthy peers. It is worth mentioning here that the quality of life perception studies show that the loss of sense of taste and smell is: 1) considered to be the fifth (out of the total of ninety two) worst symptom of PD; 2) considered to be the second worst non-motor symptom of PD[51].

\section{DIFFERENTIAL DIAGNOSIS OF PARKINSON'S SYNDROMES BASED ON THE OLFACTORY FUNCTION}

Validated psychometric olfactory function tests appeared in the mid 1980s of the twentieth century [25]. They make it possible to differentiate between persons suffering from PD and healthy individuals as well as to differentiate between various Parkinson's syndromes more accurately than in the case of the motor function [52]. The sensitivity and specificity of the olfactory function tests is in this regard higher than in the case of other diagnostic methods such as PET and SPECT imaging [53]. The inclusion of the olfactory function evaluation increased the accuracy of the PD diagnosis to $90 \%$ [15].

Knowledge of olfactory dysfunction in PD may be very helpful in the differential diagnosis. Parkinson's disease is difficult to differentiate in the early phase from progressive supranuclear palsy (PSP) or multi-system atrophy (MSA) - and in the case of these disorders olfactory dysfunction is very rarely observed and if they are, the patients display a much higher level of the olfactory function compared to PD patients [54]. In patients with diagnosed corticobasal degeneration, a normal level of olfactory function is observed. MSA is the second (after PD) the most frequent Parkinson's syndrome [10] - no neuropathological changes in the olfactory bulb are observed in this disease, but it was confirmed that other regions of the brain involved in the processing olfactory information are affected by these changes. Thus, MSA patients experience problems with odour identification, but they are much less severe than in PD. Anosmia also occurs very rarely in the progressive basal ganglia palsy - if it is diagnosed, it is worth reconsidering the revision być dobrym predyktorem rozwoju komplikacji neuropsychiatrycznych w PD. W innym studium trwającym 10 lat uzyskano podobne wyniki. U 46\% badanych pacjentów cierpiących na PD, u których na początku badania zdiagnozowano hipozmię, w ciągu 10 lat rozwinęło się otępienie. Dla porównania, konwersja w otępienie wystąpiła jedynie u 21\% pacjentów normozmicznych [35].

Oszacowano stopnie ryzyka rozwoju zaburzeń węchowych w przebiegu PD na podstawie badań podłużnych [50]. Na ich podstawie stwierdzono, że pacjentów z PD w wieku 45-65 lat cechuje 12,74 razy wyższe prawdopodobieństwo anosmii lub hiposmii w porównaniu $\mathrm{z}$ osobami zdrowymi w tym samym wieku. W przypadku pacjentów z PD w wieku $>80$ lat ryzyko to jest 74,01 razy wyższe $\mathrm{w}$ porównaniu ze zdrowymi rówieśnikami. Warto $\mathrm{w}$ tym miejscu wspomnieć, że badania poczucia jakości życia wskazują, że utrata zmysłu smaku i węchu jest uważana: 1) za piąty w kolejności (z 92 ogółem) najbardziej dokuczliwy objaw PD, 2) za drugi w kolejności najbardziej dokuczliwy objaw niemotoryczny PD [51].

\section{DIAGNOZA RÓŻNICOWA ZESPOŁÓW PARKINSONOWSKICH BAZUJĄCA NA SPRAWNOŚCI WĘCHOWEJ}

Zwalidowane psychometrycznie testy sprawności węchowej pojawily się w połowie lat 80 . XX w. [25]. Pozwalają one różnicować osoby cierpiące na PD od osób zdrowych oraz różnicować pomiędzy różnymi zespołami parkinsonowskimi $\mathrm{z}$ większą trafnością niż testy sprawności motorycznej [52]. Czułość i specyficzność testów sprawności węchowej jest w tym względzie wyższa niż innych metod diagnostycznych, takich jak obrazowanie metodą PET i SPECT [53]. Włączenie oceny sprawności węchowej podnosi trafność diagnozy PD do rzędu 90\% [15].

Wiedza na temat zaburzeń węchowych w PD może być bardzo pomocna w diagnozie różnicowej. Chroroba Parkinsona jest w początkowej fazie trudna do zróżnicowania z postępującym porażeniem nadjądrowym (progressive supranuclear palsy - PSP) lub zanikiem wieloukładowym (multi-system atrophy - MSA). W tych ostatnich zaburzeniach bardzo rzadko stwierdza się dysfunkcje węchowe, a jeśli nawet, to pacjenci prezentują istotnie wyższy poziom funkcjonowania węchowego w porównaniu z populacją chorych na PD [54]. U pacjentów ze zdiagnozowanym zwyrodnieniem korowo-podstawnym stwierdza się normalny poziom funkcji węchowych. Zanik wieloukładowy jest drugim po PD najczęstszym zespołem parkinsonowskim [10] - nie stwierdzono zmian neuropatologicznych $\mathrm{w}$ opuszce węchowej w przebiegu tej choroby, ale potwierdzono, że dotknięte nimi są inne obszary mózgu zaangażowane $\mathrm{w}$ procesy przetwarzania informacji węchowych. $Z$ tego powodu pacjenci z MSA mają problemy $\mathrm{z}$ identyfikacją węchową, aczkolwiek są 
of the diagnosis. Smell tests seem to have no clinical value in Huntington's disease [38].

It was also found that response to a particular odour makes it possible to differentiate between healthy subjects and people suffering from PD [50]. Researchers interested in the development of quick screening tests based on the olfactory function should focus on scents associated with food as scents that were not associated with food did not have such good classification indicators. It was found that: 1) peppermint and fish scents were the scents that were most correctly identified by the control group; 2) apple scent was rarely identified by both groups participating in the study - PD patient group and control group; 3) with the exception of cinnamon and garlic, PD patients showed significant impairment of the ability to identify individual scents compared to healthy subjects; 4) reactions to coffee, peppermint and anise scents demonstrated the greatest differences between groups. It is worth mentioning that in PD patients compulsive eating was negatively correlated with olfactory dysfunction - the worse sense of smell, the lower tendency to compulsive eating [55].

\section{SUMMARY}

Hyposmia is a common prodromal symptom of PD. It precedes cognitive and motor symptoms by a few years. Olfactory dysfunction is commonly found in PD and may be helpful in the diagnosis of this disease and differential diagnosis of Parkinson's syndromes. In PD no correlations are found between the olfactory function and the degree of cognitive deterioration. In any event, they are not so clear. In PD, olfactory dysfunction is more massive and develops much faster than in other neurodegenerative diseases. Many authors emphasise that in PD the level of olfactory function is independent of the duration of the disease and severity of motor symptoms. Particularly evident is the impairment of the ability to identify odours and differentiate between odours, with food scents being the most difficult for patients to identify. one dużo mniej nasilone niż w PD. Anosmia występuje również bardzo rzadko w postępującym porażeniu jąder podstawy - jeśli się ją stwierdzi, warto również rozważyć rewizję diagnozy. Badanie węchu wydaje się nie mieć natomiast wartości klinicznej w chorobie Huntingtona [38].

Stwierdzono, że reakcja na konkretny zapach pozwala także różnicować osoby zdrowe od chorych na PD [50]. Badacze zainteresowani stworzeniem szybkich testów przesiewowych bazujących na sprawności węchowej powinni skupić się na zapachach związanych z żywnością, gdyż zapachy niezwiązane z żywnością nie miały tak dobrych wskaźników klasyfikacyjnych. Zaobserwowano, że: 1) zapachy mięty pieprzowej i ryb należały do najczęściej poprawnie identyfikowanych zapachów przez osoby $\mathrm{z}$ grupy kontrolnej, 2) zapach jabłek był rzadko identyfikowany przez obie grupy badane - PD i kontrolną, 3) z wyjątkiem cynamonu i czosnku, pacjenci z PD wykazywali istotne zaburzenie zdolności identyfikowania pojedynczych zapachów w porównaniu z osobami zdrowymi, 4) reakcje na zapach kawy, mięty pieprzowej i anyżu cechowała największe zróżnicowanie między grupami. Warto wspomnieć, że u pacjentów z PD kompulsywne objadanie się było negatywnie powiązane $\mathrm{z}$ dysfunkcją węchową - im gorszy węch, tym mniejsza tendencja do kompulsywnego objadania się [55].

\section{PODSUMOWANIE}

Hipozmia jest częstym objawem prodromalnym PD i wyprzedza objawy poznawcze oraz motoryczne o kilka lat. Zaburzenia węchowe powszechnie występują w PD i mogą być pomocne $\mathrm{w}$ rozpoznawaniu tej choroby oraz w diagnozie różnicowej zespołów parkinsonowskich. W PD nie stwierdza się związków między sprawnością węchową a stopniem deterioracji poznawczej, a w każdym razie nie są one tak wyraźne. W PD zaburzenia sprawności węchowej są bardziej masywne i rozwijają się znacznie szybciej w porównaniu z innymi chorobami neurozwyrodnieniowymi. Wielu autorów podkreśla, że w $\mathrm{PD}$ poziom sprawności węchowej jest niezależny od czasu trwania choroby i nasilenia objawów motorycznych. Szczególnie wyraźne są zaburzenia identyfikacji i rozróżniania zapachów, przy czym największe trudności pacjentom z PD sprawiają zapachy żywności.

\section{Conflict of interest/Konflikt interesu}

Absent./Nie występuje.

Financial support/Finansowanie

Absent./Nie występuje. 


\section{References/Piśmiennicłwo}

1. Teixeira C, Cerqueira N, Ferreira A. Unravelling the olfactory sense: From the gene to odor perception. Chem Senses 2016; 41: 105-121.

2. Martin GN. The Neuropsychology of Smell and Taste. Psychology Press, New York 2013.

3. Śmigórska A, Śmigórski K. Podstawy neuroanatomiczne ludzkiego układu węchowego. Neuropsychiatria i Neuropsychologia 2016; 11: 1-10.

4. Mackay-Sim A, Royet JP. Structure and function of the olfactory system. In: Brewer W, Castle D, Pantelis C (eds.). Olfaction and the Brain. Cambridge University Press, Cambridge 2006; 3-27.

5. Lehrner JP, Bruecke T, Dal-Bianco T. Olfactory functions in Parkinson's disease and Alzheimer's disease. Chem Senses 1997; 22: 105-110.

6. Devanand DP, Michaels-Marston KS, Liu X. Olfactory deficits in patients with Mild Cognitive Impairment predict Alzheimer's disease at follow-up. Am J Psychiatr 2000; 157: 1399-1405.

7. Tabert MH, Albert SM, Borukhova-Milov L. Functional deficits in patients with Mild Cognitive Impairment: Prediction of AD. Neurology 2002; 58: 758-764.

8. Brunjes PC, Illig KR, Meyer EA. A field guide to the anterior olfactory nucleus (cortex). Brain Res Rev 2005; 50: 305-335.

9. de Araujo IET, Rolls ET, Kringelbach F. Taste-olfactory convergence and the representation of the pleasantness of flavour in the human brain. Eur J Neurosci 2003; 18: 2059-2068.

10. Kovacs T. Mechanisms of olfactory dysfunction in aging and neurodegenerative disorders. Ageing Res Rev 2004; 3: $215-232$.

11. Jayant MP, Wroblewski KE, Kern DW, et al. The rate of age-related olfactory decline among the general population of older U.S. adults. J Gerontol A: Biol Sci and Med Sci 2005; 70: 1435-1441.

12. Wehling E, Nordin S, Espeseth T, Reinvang I, Lundervold AJ. Unawareness of olfactory dysfunction and its association with cognitive functioning in middle aged and old adults. Arch Clin Neuropsychol 2011; 26: 260-269.

13. Attems J, Walker L, Jellinger KL. Olfaction and Aging: a Mini-Review. Gerontology 2015; 61: 485-490.

14. Doty RL, Kamath V. The influences of age on olfaction: a review. Front Psychol 2014; 5: 1-20.

15. Takeda A, Kikuchi A, Matsuzaki-Kobayashi M, Sugeno N, Itoyama Y. Olfactory dysfunction in Parkinson's disease. J Neurol 2007; 254: IV/2-IV/7.

16. Marras C, Chaudhuri KR. Nonmotor features of Parkinson's disease subtypes. Mov Disord 2016; 31: 1095-1102.

17. Sharer JS, Leon-Sarmiento FE, Morley JF, Weintraub D, Doty RL. Olfactory dysfunction in Parkinson's disease: Positive effects of cigarette smoking. Mov Disord 2015; 30: 859-862.

18. Kawasaki I, Baba T, Takeda A, Mori E. Loss of awareness of hyposmia is associated with mild cognitive impairment in Parkinson's disease. Parkinsonism Relat Disord 2016; 22: 74-79.

19. Saito S, Ayabe-Kanamura S, Takashima Y, et al. Development of a smell identification test using a novel stick-type odor presentation kit. Chem Senses 2006; 31: 379-391.

20. Iijima M, Kobayawa T, Saito S, Osawa M. Smell identification in Japanese Parkinson's disease patients: using the odor stick identification test for Japanese subjects. Intern Med 2008; 31: 379-391.

21. Bohnen NI, Muller ML, Kotagal V, et al. Olfactory dysfunction, central cholinergic integrity and cognitive impairment in Parkinson's disease. Brain 2010; 133: 1747-1754.

22. Baba T, Takeda A, Kikuch A, et al. Association of olfactory dysfunction and brain. Metabolism in Parkinson's disease. Mov Disord 2011; 26: 621-628.

23. Lee EY, Eslinger PJ, Du G, Kong L, Lewis MM, Huang X. Olfactory-related cortical atrophy is associated with olfactory dyfsunction in Parkinson's disease. Mov Disord 2014; 29: 1205-1208.

24. Lee JE, Kyoo H, Ham JH, Song SK, Sohn YH, Lee PH. Olfactory performance acts as a cognitive reserve in nondemented patients with Parkinson's disease. Parkinsonism Relat Disord 2014; 20: 186-191.

25. Doty RL. Olfaction in Parkinson's disease and related disorders. Neurobiol Dis 2012; 46: 527-552.

26. Ross GW, Petrovitch H, Abott RD, Tanner CM, Popper J. Association olfactory dysfunction with risk for future Parkinson's disease. Ann Neurol 2008; 63: 167-173.

27. Hawkes CH, Del Tredici K, Braak H. Parkinson's disease: a dual hit hypothesis. Neuropathol Appl Neurobiol 2007; 33: 599-614.

28. Lehrner JP, Bruecke T, Dal-Bianco T, Gatterer G, Kryspin-Exner I. Olfactory functions in Parkinson's disease and Alzheimer's disease. Chem Senses 1997; 22: 105-111.

29. Mahlknecht $P$, Gasperi A, Willeit $P$, et al. Prodromal Parkinson's disease as defined per MDS research criteria in the general elderly community. Mov Disord 2016; 31: 1405-1408.

30. Berardelli A, Wenning GK, Antonini A, Berg D, Bloem BR, Bonifati V. EFNS/MDS-ES recommendations for the diagnosis of Parkinson's disease. Eur J Neurol 2013; 20: 16-34.

31. Ponsen M, Stoffers D, Gooji J, van Eck-Smith BLF, Wolters ECh. Idiopathic hyposmia as a preclinical sign of Parkinson's disease. Ann Neurol 2004; 56: 173-181.

32. Shah M, Deeb J, Fernando M, Noyce A, Visentin E. Abnormality of taste and smell in Parkinson's disease. Parkinsonism Relat Disord 2009; 15: 232-237.

33. Fullard ME, Tran B, Xie ShX, Toledo JB, Scordia Ch. Olfactory impairment predicts cognitive decline in early Parkinson's disease. Parkinsonism Relat Disord 2016; 25: 45-51.

34. Doty R. The olfactory vector hypothesis of neurodegenerative disease: Is it viable? Ann Neurol 2008; 63: 7-15.

35. Domelloef ME, Lundin KF, Edstroem M, Forsgren L. Olfactory dysfunction and dementia in newly diagnosed patients with Parkinson's disease. Parkinsonism Relat Disord 2017; 38: 41-47. 
36. Driver-Dunckley E, Adler CH, Hentz JG, Dugger BN, Shill HA. Olfactory dysfunction in incidental Lewy body disease and Parkinson's disease. Parkinsonism Relat Disord 2014; 20: 1260-1262.

37. Rossi M, Escobar AM, Bril A, et al. Motor features in Parkinson's disease with normal olfactory function. Mov Disord 2016; 31: 1414-1417.

38. Hawkes CH. Olfaction in neurodegenerative disorder. Mov Disord 2003; 18: 361-372.

39. Zhu M, Li M, Ye D, Jiang W, Lei T. Sensory symptoms in Parkinson's disease: Clinical features, pathophysiology, and treatment. J Neurosci Res 2016; 94: 685-692.

40. Siderowf A, Jennings D, Eberly S, et al.; PARS Investigators. Impaired olfaction and other prodromal features in Parkinson At-Risk Syndrome. Mov Disord 2012; 27: 406-412.

41. Sengoku R, Matsushima S, Bono K, Sakuta K, Yamazaki M. Olfactory function combined with morphology distinguishes Parkinson's disease. Parkinsonism Relat Disord 2015; 21: 771-777.

42. Paschen L, Schmidt N, Wolff S, Cnyrim C, Eimeren T. The olfactory bulb volume in patients with idiopathic Parkinson's disease. Eur J Neurol 2015; 22: 1068-1107.

43. Doty RL, Riklan M, Deems DA, Reynolds C, Stellar S. The olfactory and cognitive deficits in Parkinson's disease: Evidence for independence. Ann Neurol 1989; 25: 166-171.

44. Pfeiffer RF. Non-motor symptoms in Parkinson's disease. Parkinsonism Relat Disord 2016; 22: S119-S122.

45. OndoW, Lai D. Olfaction testing in patients with tremor-dominant Parkinson's disease: Is this a different condition? Mov Disord 2005; 20: 471-475.

46. Mrochen A, Marxreiter F, Kohl Z, Schlachetzki J, Renner B. From sweet to sweat: Hedonic olfactory range is impaired in Parkinson's disease. Parkinsonism Relat Disord 2016; 22: 9-14.

47. Hasegawa K, Onuma H, Nakamura S, Kumon A, Horiuchi E. Is there a relationship between olfactory dysfunction and depression in Parkinson's disease? Parkinsonism Relat Disord 2016; 22: e56-e57.

48. Morley JF, Weintraub D, Mamikonyan E, Moberg PJ, Siderowf AD. Olfactory dysfunction is associated with neuropsychiatric manifestation in Parkinsons's disease. Mov Disord 2011; 26: 2051-2057.

49. Stephenson R, Houghton D, Sundararajan S, Doty RL, Stern M. Odor identification deficits are associated with increased risk of neuropsychiatric complications in patients with Parkinson's disease. Mov Disord 2010; 25: 2099-2104.

50. Casjens S, Eckert A, Woitalla D, et al. Diagnostic value of the impairment of olfaction in Parkinson's disease. PLoS One 2013; 8: e64735.

51. Knudsen K, Flensborg Damholdt M, Mouridsen K, Borghammer P. Olfactory function in Parkinson's disease effects of training. Acta Neurol Scand 2015; 132: 395-400.

52. Bohnen NI, Studenski SA, Constantine GM, Moore RY. Diagnostic performance of clinical motor and non-motor tests of Parkinson disease: a matched case-control study. Eur J Neurol 2008; 15: 685-691.

53. Deeb J, Shah M, Muhammed N, et al. A basic smell test is as sensitive as a dopamine transporter scan: comparison of olfaction, taste and DaTSCAN in the diagnosis of Parkinson's disease. QJM 2010; 103: 941-952.

54. Tissingh G, Berendse HW, Bergmans P, DeWaard R, Drukarch B. Loss of olfaction in de novo and treated Parkinson's disease: Possible implications for early diagnosis. Mov Disord 2001; 16: 41-46.

55. Goncalves A, Mendes A, Vila-Cha N, Moreira I, Fernandes J. Compulsive eating and olfaction in Parkinson's disease. Parkinsonism Relat Disord 2016; 22: e61. 